\title{
PENGEMBANGAN STRATEGI BISNIS PRODUK OLAHAN SUSU XYZ DENGAN PENDEKATAN BUSINESS MODEL CANVAS
}

\author{
DEVELOPMENT OF XYZ'S MILK PRODUCTS BUSINESS STRATEGY USING BUSINESS MODEL CANVAS \\ APPROACH
}

\author{
Nizza Nadya Rachmani*)1, Arief Daryanto*), and Siti Jahroh ${ }^{*}$ \\ *) Sekolah Bisnis, IPB University \\ Jl. Raya Pajajaran, Bogor 16151
}

\begin{abstract}
Tight competition of dairy product's market share makes XYZ had to distinguish their products from the competitors. A way to differentiate XYZ products from competitors was to create a business strategy. This study aimed to (1) identify the XYZ business model, (2) to evaluate the present XYZ business model, and (3) to formulate a business strategy from the evaluation of the present business model. This research was conducted using descriptive methods and tools, Business Model Canvas, and SWOT analysis. Respondents were selected using purposive sampling. The results of this study showed the identification of 9 elements of business models. The evaluation results indicated that the major strengths came from customer relationships element caused by a close relationship from companies to customers using dedicated personal assistance. The main weakness was the cost structure element because the production had not run efficiently. The biggest opportunity came from the customer segment element because the emergence of new customer segmentation had not been well managed. The biggest threat came from the key resources element due to limitations in getting raw materials. The formulated strategy was to optimize key resources element by creating a company-owned farm near the factory to guarantee the quantity, quality, and sustainability of raw materials.
\end{abstract}

Keywords: dairy industry, business sustainability, business evaluation, business model canvas, corporate strategy

\begin{abstract}
Abstrak: Ketatnya persaingan pangsa pasar produk olahan susu membuat XYZ harus mampu membedakan dirinya sendiri dengan pesaing-pesaingnya. Salah satu cara untuk yang bisa dilakukan untuk bisa membedakan produk XYZ dengan pesaing adalah dengan membuat sebuah strategi bisnis yang dikembangkan setelah mengetahui model bisnis yang dijalankan dan melakukan evaluasi terhadap model bisnis yang dilakukan. Penelitian ini bertujuan (1) mengidentifikasi model bisnis XYZ dengan pendekatan business model canvas (BMC), (2) mengevaluasi model bisnis XYZ yang telah dilakukan, dan (3) menyusun strategi perbaikan dari hasil evaluasi model bisnis XYZ. Penelitian ini dilakukan dengan menggunakan metode deskriptif dengan alat analisis BMC, dan SWOT (Strength, Weakness, Opportunity, Weakness). Pemilihan responden dilakukan secara purposive sampling. Hasil dari penelitian ini memperlihatkan identifikasi terhadap 9 elemen model bisni. Hasil evaluasi menunjukkan adanya kekuatan utama dari elemen hubungan pelanggan yang berasal dari program pendampingan dari perusahaan kepada pelanggan secara langsung. Sementara itu kelemahan utama terdapat pada struktur biaya karena kegiatan produksi yang belum berjalan secara efisien. Peluang terbesar berada pada segmen pelanggan karena munculnya segmentasi pelanggan baru yang belum dikelola lebih dalam dan ancaman terbesar berada pada sumberdaya kunci karena keterbatasan dalam mendapatkan bahan baku. Strategi yang dapat dilakukan adalah mengoptimalkan elemen sumberdaya kunci dengan membuat peternakan milik perusahaan yang berada berdekatan dengan lokasi pabrik sehingga kuantitas, kualitas dan keberlanjutan bahan baku dapat terjamin.
\end{abstract}

Kata kunci: industri pengolahan susu, keberlanjutan bisnis, evaluasi bisnis, model bisnis kanvas, strategi perusahaan

\footnotetext{
${ }^{1}$ Alamat Korespondensi:

Email: nnadyar@gmail.com
} 


\section{PENDAHULUAN}

Susu adalah salah satu minuman yang dibutuhkan untuk melengkapi kebutuhan gizi harian. Namun konsumsi susu dan produk turunan masyarakat Indonesia saat ini masih lebih rendah dibandingkan dengan negaranegara di ASEAN. Pada tahun 2012 konsumsi susu di Indonesia sebesar 14,6 liter susu per kapita per tahun, sementara jumlah konsumsi di negara ASEAN yang lain lebih besar daripada Indonesia.

Konsumsi susu di Indonesia telah mengalami peningkatan walaupun masih berada di bawah negaranegara ASEAN. Peningkatan konsumsi susu dan produk turunannya berjalan seiring peningkatan daya beli masyarakat, peningkatan jumlah penduduk dan tingginya kesadaran masyarakat terhadap kesehatan (Oktariani, 2014). Kementan pada tahun 2016 telah melakukan perhitungan perkiraan pertambahan jumlah konsumsi susu segar di Indonesia berkisar 4\% per tahun.

Kebutuhan susu nasional tidak berjalan seiring dengan produksi susu dalam negeri. Produksi susu nasional saat ini berkisar 23\% dari kebutuhan susu nasional atau sebesar 0,85 juta ton, sedangkan $77 \%$ kebutuhan susu atau sebesar 2,85 juta ton dipenuhi dengan mengimpor susu sapi yang berasal dari Australia dan Selandia Baru dalam bentuk susu skim dan susu bubuk (Kemenperin, 2017). Sementara itu, Farid dan Sukesi (2011) mengatakan bahwa ketergantungan terhadap bahan baku susu impor mengakibatkan devisa negara terkuras, kemanan jangka panjang tidak terjamin, peningkatan pengangguran, kurangnya kesejahteraan peternak, dan penurunan konsumsi susu segar yang berkualitas berbahan baku susu segar dalam negeri.

Pemerintah melalui Permentan No. 26 Tahun 2017 mengatur mengenai kebijakan yang diharapkan dapat meningkatkan kemampuan peternak dan juga industri pengolahan susu di Indonesia. Pasal 23 memuat tentang pelaku usaha susu yang wajib menyerap susu segar dalam negeri. Adanya Permentan No. 26 Tahun 2017 membuat adanya persaingan dalam mendapatkan bahan baku susu segar di kalangan industri pengolahan susu.roduksi susu segar dalam negeri saat ini diserap oleh indutri pengolahan susu. Tercatat ada 14 industri pengolahan susu yang menyerap produksi susu segar dalam negeri.
Salah satu industri pengolahan susu yang menyerap produksi susu dalam negeri adalah XYZ. XYZ merupakan salah satu satu industri susu yang tidak memiliki peternakan sendiri dan menjalin kerja sama dengan koperasi-koperasi susu petani daerah sebagai pemasok utama. XYZ mempunyai beberapa produk olahan susu, khususnya yogurt yang dibuat karena adanya keterbatasan pada susu berupa masa kedaluwarsa yang cukup cepat. Oleh karena itu, XYZ melakukan inovasi untuk mengolah susu dengan menciptakan produk olahan susu dengan masa kedaluwarsa yang lebih lama.

Produksi produk olahan susu XYZ mengalami peningkatan sebesar $20 \%$ per tahun. Untuk pasar yogurt sendiri, produk XYZ menguasai sekitar 50\% pangsa pasar dibandingkan pesaingnya. Namun untuk produk susu segar, produk XYZ diperkirakan hanya mempunyai pangsa pasar yang lebih kecil, berkisar $10 \%$ dari seluruh pesaing.

Ketatnya persaingan dalam mendapatkan pangsa pasar produk olahan susu membuat XYZ harus mampu membedakandirinyasendiridengan pesaing-pesaingnya agar bisa tetap bertahan di industri ini. Salah satu cara untuk mengetahui apa yang bisa dilakukan untuk bisa membedakan produk XYZ dengan pesaing adalah dengan membuat sebuah strategi bisnis dimana strategi bisnis itu dapat dikembangkan setelah mengetahui model bisnis yang dijalankan dan melakukan evaluasi terhadap model bisnis yang dilakukan tersebut. Pengkajian model bisnis yang tepat akan membuat suatu usaha bisnis dapat berjalan maksimal (Chesbrough, 2005). Salah satu alat untuk mengetahui model bisnis yang dijalankan dapat berjalan secara berkelanjutan adalah dengan menggunakan pendekatan Business Model Canvas (BMC). BMC adalah salah satu model bisnis yang dikembangkan oleh Osterwalder dan Pigneur (2010). BMC memiliki keunggulan untuk memudahkan suatu organisasi atau perusahaan mengevaluasi kembali aktivitas yang dilakukan untuk pengembangan bisnis. Penelitian ini akan menggunakan BMC untuk memetakan model bisnis yang ada pada XYZ yang selanjutnya akan dianalisa dengan SWOT sebelum disempurnakan menjadi model bisnis yang lebih baik. Penelitian ini bertujuan (1) mengidentifikasi model bisnis XYZ dengan pendekatan BMC, (2) mengevaluasi model bisnis XYZ yang telah dilakukan, (3) menyusun strategi perbaikan dari hasil evaluasi model bisnis XYZ. 


\section{METODE PENELITIAN}

Penelitian ini dilakukan di pabrik XYZ yang beralamat di Sentul, Bogor, dan Kantor Pusat, yang beralamat di Meruya, Jakarta Barat. Penelitian ini dimulai pada bulan Oktober 2017 hingga Agustus 2018. Penelitian ini menggunakan data primer dan data sekunder. Data primer diperoleh dari hasil observasi/pengamatan langsung, wawancara mendalam dengan manajemen XYZ, dan wawancara terhadap ahli/pakar dalam industri susu. Informasi yang diperlukan meliputi pemetaan model bisnis sembilan elemen BMC dan informasi faktor internal dan eksternal perusahaan yang akan digunakan sebagai dasar dalam pembuatan model bisnis perbaikan bagi perusahaan. Data sekunder diperoleh dengan mengakses informasi/data dari instansi terkait seperti Dirjen Peternakan dan Kesehatan Hewan Kementerian Pertanian, Badan Pusat Statistik Indonesia, Kementerian Perindustrian, dan sumber data lainnya yang relevan dengan topik penelitian yang dapat berasal jurnal ilmiah, buku, dan working paper.

Teknik penetapan sampel dilakukan dengan menggunakan teknik pengambilan contoh tanpa peluang (non probability sampling). Adapun, teknik penentuan responden dilakukan secara sengaja (purposive sampling) melalui pendekatan expertise judgment. Terdapat lima tahapan pengolahan dan analisis data yang dilakukan dalam penelitian ini, yaitu 1) Analisis deskriptif untuk mendapatkan gambaran umum secara menyeluruh mengenai kondisi umum perusahaan dengan menggunakan pendekatan non statistik, 2) Pemetaan dan identifikasi model bisnis dengan pendekatan BMC yang dilakukan untuk mengetahui bagaimana model bisnis yang sedang dilakukan, 3) Analisis SWOT dilakukan untuk mengevaluasi sembilan elemen BMC yang ada pada saat ini agar dapat melakukan perbaikan pada model bisnis yang ada saat ini, 4) Pembuatan strategi perbaikan dari hasil evaluasi model bisnis yang ada, dan 5) Implikasi manajerial. Secara keseluruhan, sistematika penelitian dituangkan pada kerangka pemikiran penelitian yang digambarkan pada Gambar 1.

\section{HASIL}

\section{Identifikasi Model Bisnis XYZ}

Penelitian ini melibatkan orang-orang yang terkait dengan pengelolaan XYZ untuk mengetahui model bisnis XYZ saat ini. Berdasarkan hasil penelitian terhadap sembilan elemen BMC maka gambaran kanvas model bisnis yang dijalankan oleh XYZ adalah sebagai berikut:

\section{Segmen Pelanggan (Customer Segment)}

Segmen pelanggan dari suatu perusahaan bertujuan menjangkau dan melayani pelanggan atau konsumen dari perusahaan tersebut. Segmen pelanggan XYZ secara umum ditujukan bagi masayarakat Indonesia. Namun, apabila melihat segmen pelanggannya secara khusus, segmen pelanggan XYZ ditujukan kepada keluarga dengan kondisi ekonomi menengah-atas.

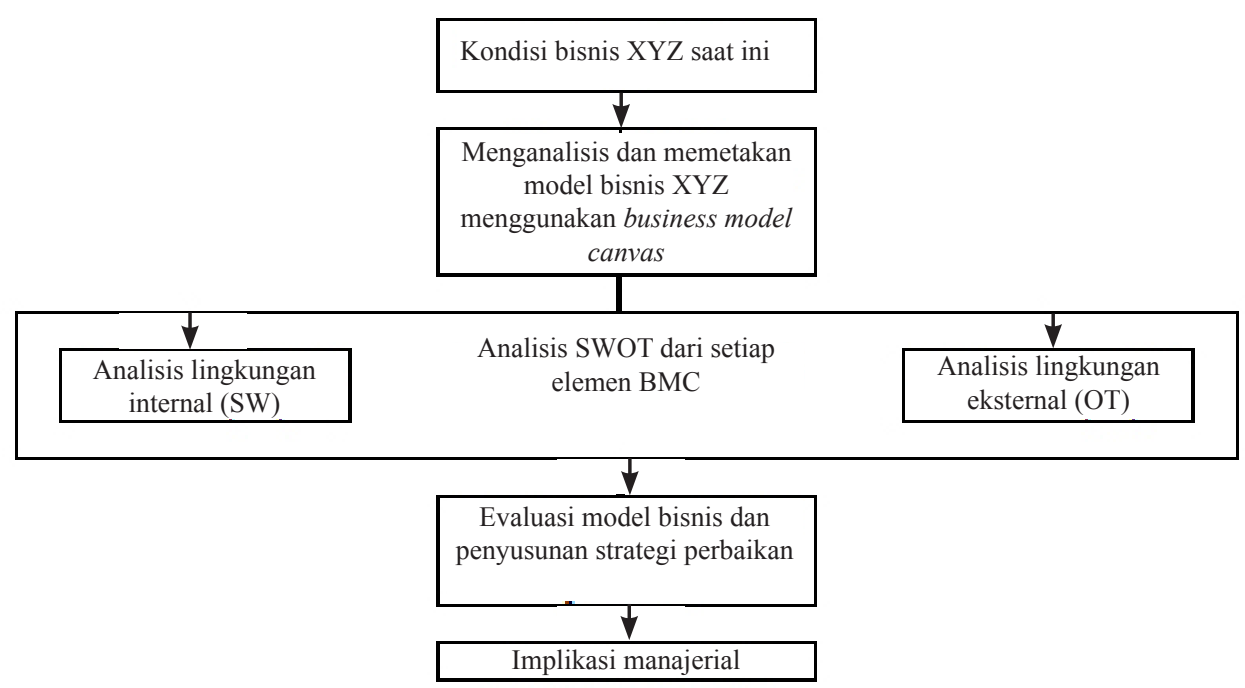

Gambar 1. Kerangka pemikiran penelitian 


\section{Dalil Nilai (Value Proposition)}

Terdapat lima dalil nilai yang ditawarkan oleh XYZ, yaitu sifat baru (newness), kinerja (performance), image (brand), kemudahan dalam mengakses (accessibility), dan kenyamanan/kegunaan (convenience/usability). Kebaruan yang dihadirkan oleh XYZ adalah dengan menawarkan produk yoghurt cair dalam kemasan botol kepada pelanggan. Penilaian kinerja ini dapat dilihat dari kualitas produk dimana produk yang dihasilkan tersebut bersifat segar. Kualitas produk XYZ yang terbukti baik dan label premium product tentu akan menaikkan status pembeli. Status pembeli akan naik karena produk yang bersifat premium dan lebih banyak dikonsumsi oleh kalangan keluarga menengah ke atas. Susanto et al. (2017) mengatakan bahwa kualitas produk yang tinggi (grade super) dapat mempertahankan dan memeroleh harga jual produk pada posisi tertinggi, sedangkan produk dengan kualitas rendah dapat mendapatkan penawaran harga jual yang lebih rendah. Produk XYZ ini memiliki kelebihan dalam tekstur yogurt cair sehingga cara mengonsumsinya pun menjadi lebih mudah daripada mengonsumsi yogurt kental dalam kemasan mangkok yang harus menggunakan sendok. Saat ini produk-produk XYZ sangat mudah didapatkan di retail besar dan kecil juga toko kelontong.

\section{Saluran (Channels)}

Terdapat beberapa saluran yang dimiliki oleh XYZ seperti saluran langsung dan saluran tidak langsung. Saluran langsung dilakukan dengan menyampaikan produk XYZ langsung menuju pelanggannya yang dilakukan dengan penjualan produk $\mathrm{XYZ}$ di toko langsung ataupun program sales penjual langsung dari perusahaan. Sementara itu, saluran tidak langsung dilakukan melalui kerjasama dengan mitra seperti supermarket, hypermarket, minimarket, distributor, dan toko kelontong.

\section{Hubungan Pelanggan (Customer Relationship)}

Sebagai produsen produk olahan susu XYZ harus menjaga hubungan dengan pelanggan karena bagi $\mathrm{XYZ}$ pelanggan adalah raja. Cara yang digunakan $\mathrm{XYZ}$ untuk menjaga hubungan yang baik dengan konsumennya adalah dengan adanya saluran komplain (melalui internet, direct call), dan saluran komunikasi melalui media sosial mengenai informasi produk terbaru. Selain kedua saluran tersebut, XYZ juga menjaga pelanggannya melalui program sales penjualan langsung yang berada di sekitar masyarakat.

\section{Aliran Pendapatan (Revenue Stream)}

Pendapatan XYZ saat ini berasal dari berbagai macam penjualan produk $\mathrm{XYZ}$ dimana pendapatan terbesar XYZ berasal dari produk yoghurt XYZ. Produk $\mathrm{XYZ}$ yang mudah didapatkan dimana saja membuat pelanggan dapat membayar produk tersebut dengan cara yang lebih disukai pelanggan.

\section{Sumberdaya Kunci (Key Resources)}

Sumber daya kunci yang dibutuhkan untuk menciptakan layanan jasa dan juga produk di XYZ terbagi menjadi dua, yaitu sumber daya yang bisa terlihat (tangible) dan sumber daya yang tidak bisa dilihat (intangible). Sumber daya tangible yang terdapat di XYZ sumber daya manusia, bahan baku, dan fasilitas fisik. Sementara itu sumber daya intangible yang dimiliki oleh XYZ adalah merek, ilmu pengetahuan yang berkaitan dengan kemampuan sumber daya manusia dalam keahlian bidangnya (intellectual).

\section{Aktivitas Kunci (Key Activities)}

Aktivitas kunci adalah aktivitas yang dilakukan perusahaan agar bisnisnya tetap berjalan. XYZ sendiri sebagai perusahaan pengolah susu memiliki berbagai macam aktivitas kunci yang bisa dibedakan menjadi kegiatan produksi, kegiatan pemasaran, dan kegiatan distribusi untuk menyampaikan produknya kepada pelanggan.

\section{Mitra Kunci (Key Partnerships)}

Saat ini XYZ memiliki dua mitra kunci, yaitu KUD susu sekitar dan perusahaan produksi kemasan. Produksi produk olahan susu XYZ saat ini sangat bergantung pada pasokan susu yang dikirim oleh KUD Susu dari daerah Bogor, Cianjur dan Sukabumi. Sementara itu perusahaan produksi kemasan merupakan salah satu mitra kunci karena XYZ tidak membuat kemasan sendiri. 


\section{Struktur Biaya (Cost Structure)}

Biaya terpenting yang dikeluarkan adalah biaya produksi produk olahan susu. Biaya untuk meproduksi produk XYZ berkisar sebesar 20-25\%. Selain itu, biaya juga dikeluarkan untuk membayar gaji sumber daya manusia yang berkisar 25-30\%. Adapun biaya lainnya yang dirasa cukup memberatkan adalah biaya distribusi produk, dan pembelian kemasan XYZ.

\section{Evaluasi Model Bisnis Kanvas XYZ}

Evaluasi model bisnis XYZ dilakukan dengan analisis SWOT untuk dapat mengetahui penilaian atas kekuatan, kelemahan, peluang dan ancaman pada model bisnis XYZ. Analisis ini mengacu pada pemikiran bagaimana memaksimalkan kekuatan dan peluang serta secara beriringan dapat meminimalkan kelemahan dan ancaman (Rangkuti, 2005). Model bisnis perlu dievaluasi karena lingkungan bisnis yang semakin kompleks dan cepat berubah sehingga perusahaan perlu memikirkan kembali model bisnis mereka dalam periode yang lebih sering daripada sebelumnya (Giesen et al. 2010). Hal ini sesuai dengan pernyataan Tsai et al. (2011) bahwa model bisnis ini dapat dikonfigurasi dan didesain ulang. Hasil analisis SWOT berdasarkan model bisnis kanvas XYZ pada Gambar 2.

\section{Mitra Kunci (Key Partnership)}

Nilai blok mitra kunci menunjukkan nilai kekuatan 4 (tinggi), kelemahan 2 (rendah), peluang 3,6 (tinggi) dan ancaman 3 (sedang). Kekuatan mitra kunci
XYZ dipengaruhi oleh kemampuan XYZ dalam menjaga mitra. Peluang yang sangat besar terlihat dari kemungkinan kolaborasi antara XYZ dengan mitra sehingga XYZ dapat lebih fokus pada bisnis intinya. Hasil penilaian ancaman yang tinggi mengingatkan XYZ pada kemungkinan mitra yang dapat berkolaborasi dengan pesaing.

\section{Aktivitas Kunci (Key Activities)}

Blok aktivitas kunci memiliki nilai kekuatan 3,75 (tinggi), kelemahan 2,75 (sedang), peluang 4 (tinggi), dan ancaman 3 (sedang). Kelemahan berasal dari kegiatan produksi yang belum berjalan secara efisien sementara kegiatan produksi merupakan aktivitas inti. Hal ini tentu juga menjadi peluang bagi XYZ untuk melakukan kegiatan operasi secara lebih optimal.

\section{Sumberdaya Kunci (Key Resources)}

Blok sumberdaya kunci memiliki nilai kekuatan 4 (tinggi), kelemahan 2,75 (sedang), peluang 3,8 (tinggi), dan ancaman 3,5 (tinggi). Hal yang menjadi ancaman bagi XYZ adalah ketersediaan bahan baku yang tidak mencukupi untuk kegiatan produksi. Tidak adanya peternakan sendiri mengakibatkan XYZ mengandalkan bahan baku susu segar dari partner. Saat ini persaingan dalam mendapatkan bahan baku menjadi lebih sulit karena adanya peraturan pemerintah, yaitu Permentan No. 26 Tahun 2017. Walaupun terdapat ancaman, supply bahan baku XYZ masih mampu memenuhi kegiatan produksi.

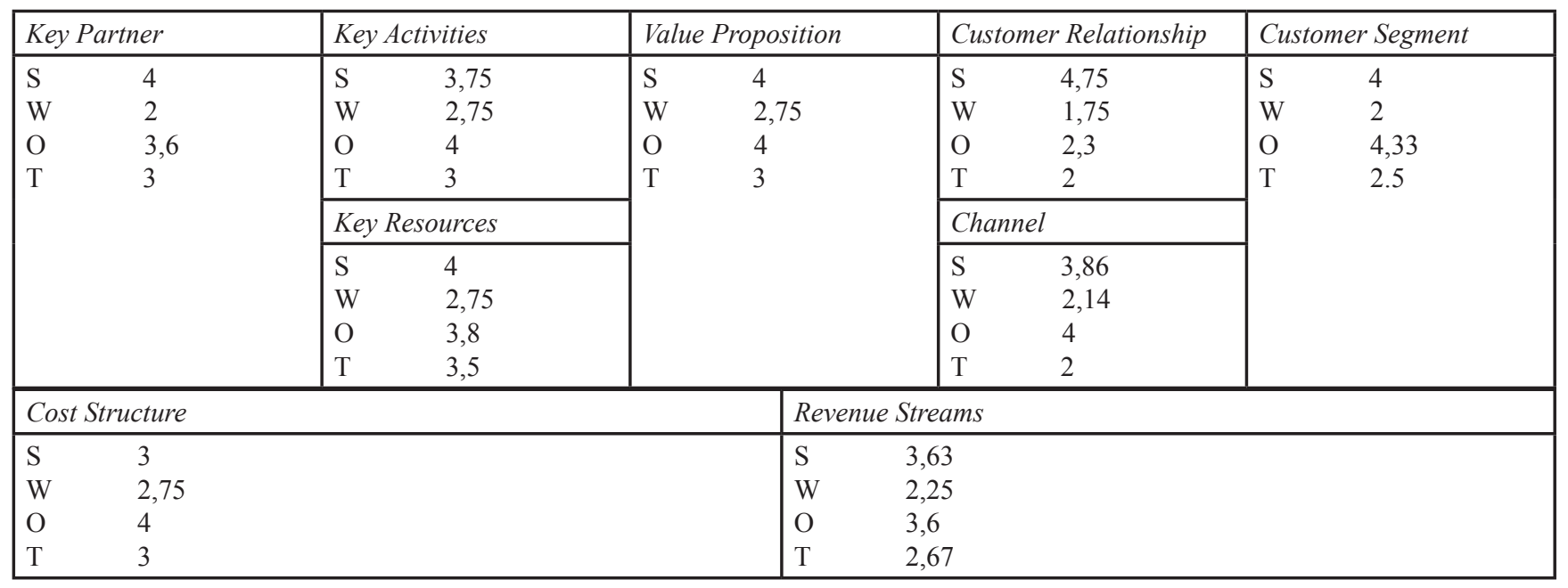

Gambar 2. Hasil analisis SWOT pada XYZ (1 (Sangat Rendah); 2 (Rendah); 3 (Sedang); 4 (Tinggi); 5(Sangat Tinggi)). 


\section{Dalil Nilai (Value Proposition)}

Blok dalil nilai memiliki nilai kekuatan 4 (tinggi), kelemahan 2,75 (sedang), peluang 4 (tinggi) dan ancaman 3 (sedang). Kekuatan dalil nilai dipengaruhi oleh kemampuan XYZ dalam mengetahui apa yang konsumen inginkan dan berusaha menciptakan produk yang sesuai dengan keinginan konsumen tersebut. Adanya varian rasa baru akan menjadi peluang bagi XYZ karena masih banyak varian rasa yang diinginkan oleh pelanggan. Sementara itu, ancaman muncul dari maraknya pesaing yang mengeluarkan produk serupa dengan XYZ.

\section{Hubungan Pelanggan (Customer Relationship)}

Blok hubungan pelanggan memiliki nilai kekuatan sebesar 4,75 (sangat tinggi), kelemahan 1,75 (rendah), peluang 2,3 (tinggi) dan ancaman 2 (rendah). Nilai kekuatan yang tinggi pada elemen ini berasal dari kemampuan XYZ yang sangat baik dalam menjaga pelanggannya dan mendapatkan pelanggan baru. Rendahnya nilai ancaman menunjukkan bahwa pesaing $\mathrm{XYZ}$ tidak mengancam keberadaan pelanggan $\mathrm{XYZ}$, dan kegiatan yang berlangsung pada elemen hubungan pelanggan ini cenderung tidak mudah dilakukan oleh pesaing.

\section{Saluran (Channels)}

Saluran memilikinilaikekuatan 3,86(tinggi), kelemahan 2,14 (rendah), peluang 4 (tinggi), dan ancaman 2 (rendah). Nilai kekuatan yang besar menunjukkan bahwa produk XYZ mampu menjangkau pelanggan dengan baik. Fase pembelian yang dilakukan oleh pelanggan dapat dilakukan dimana saja. Tingginya nilai peluang saluran menunjukkan bahwa terdapat peluang yang dapat dikembangakan seperti pengembangan penjualan produk melalui ritel dan juga pembukaan cabang distributor baru untuk menjangkau pelanggan yang selama ini belum dapat diraih. Selain itu terdapad hal yang bisa diperbaiki dari channels, yaitu perbaikan kualitas, ekeftivitas, efisiensi, orientasi konsumen dan juga ukuran saluran yang digunakan saat ini.

\section{Segmen Pelanggan (Customer Segment)}

Blok segmen pelanggan memiliki nilai kekuatan 4 (tinggi), kelemahan 2 (rendah), peluang 4,33 (tinggi) dan ancaman 2,5 (sedang). Ancaman yang terjadi saat ini adalah perusahaan pesaing yang mulai mengincar segmen pasar milik XYZ. Beberapa perusahaan pengolahan susu saat ini mulai menyasar kelas yogurt premium yang merupakan unggulan XYZ. Beberapa brand yang awalnya hanya melakukan produksi susu kini mulai merambah ke produksi yogurt. Namun nilai peluang XYZ merupakan nilai yang paling besar pada blok ini. Segmen pelanggan baru merupakan salah satu cara untuk dapat menghindari pesaing dan juga mendapatkan sumber pendapatan berkelanjutan.

\section{Struktur Biaya (Cost Structure)}

Blok struktur biaya memiliki nilai kekuatan 3 (sedang), kelemahan 2,75 (sedang), peluang 4 (tinggi), dan ancaman 2,5 (sedang). Hal yang menjadi ancaman dan harus diwaspadai dalam blok ini adalah perbaikan pengembangan struktur biaya yang harus dilakukan secepatnya karena struktur biaya saat ini masih belum belum mencapai efisiensi terbaik. Selain itu hal yang harus diwaspadai lainnya adalah perkembangan struktur biaya yang harus seimbang dengan aliran pendapatan.

\section{Aliran pendapatan (Revenue Stream)}

Blok aliran pendapatan memiliki nilai kekuatan 3,63 (tinggi), kelemahan 2,25 (rendah), peluang 3,6 (tinggi) dan ancaman 2,67 (sedang). Nilai kekuatan memiliki nilai paling tinggi karena XYZ selalu mampu berinovasi untuk menemukan produk baru yang digemari dan dicari oleh pelanggan selama ini sehingga arus pendapatan XYZ terus mengalir baik dari penjualan produk lama, maupun produk baru. Produk lama seperti yogurt XYZ yang memiliki ukuran 250 $\mathrm{ml}$ masih merupakan pendapatan utama dari penjualan produk XYZ. Sementara itu kini mulai terdapat beberapa produk baru seperti yogurt mini dan juga susu UHT XYZ yang menjadi tambahan baru pendapatan XYZ. Namun masih terdapat beberapa ancaman seperi konsumen yang masih diragukan loyalitasnya karena adanya produk-produk pesaing yang mulai mengancam keberadaan produk XYZ.

\section{Strategi Perbaikan Bisnis XYZ}

Al-Debei dan Avison (2010) mengatakan bahwa business model dapat digunakan untuk membuat arsitektur bisnis, meningkatkan operasional, value dan mengatur keuangan perusahaan secara spesifik sesuai dengan kebutuhan untuk mencapai tujuan strategis perusahaan. Hal ini dapat dilakukan dengan mengetahui elemen model bisnis apa saja yang dimiliki saat ini untuk 
dapat dikembangkan dengan melihat hasil evaluasi BMC. Masing-masing elemen blok BMC dapat menjadi titik awal pengembangan dan menghasilkan desain model bisnis baru sebanyak mungkin (Amanullah et al. 2015), seperti yang dilakukan oleh Jackson dan Harjanti (2015) yang melakukan perbaikan pada semua elemen. Pengembangan model bisnis ini memerlukan ketentuan untuk pemilihan dan pertimbangan elemen mana saja yang dapat dikembangkan. Bonazzi (2014) mengatakan bahwa setiap perusahaan akan memiliki hasil pengembangan yang berbeda karena adanya perbedaan inovasi dalam melakukan model bisnis. Hal ini juga ditegaskan oleh Dudin et al. (2015) yang mengatakan bahwa perusahaan akan memiliki hasil pengembangan yang berbeda. Oleh karena itu, terdapat 4 pertimbangan yang digunakan oleh Somantri et al. (2017) untuk menentukan kriteria pengembangan, yaitu: 1) keselarasan dengan arah pengembangan perusahaan, 2) hasil evaluasi model bisnis, 3) hasil analisis lingkungan eksternal, dan 4) pola model bisnis yang ada saat ini. Berdasarkan kriteria tersebut maka elemen yang dapat dikembangkan secara bertahap adalah sumber daya kunci.

Pemilihan elemen ini melihat dari tingginya ancaman karena adanya kemungkinan hilangnya pemasok bahan baku susu segar yang dimiliki oleh perusahaan. XYZ tidak memiliki bahan baku susu impor, namun menggunakan susu segar sebagai bahan baku utama dalam setiap produknya yang berasal dari koperasi susu atau mitra peternak susu yang ada. Oleh karena itu, pengembangan elemen sumber daya kunci dapat dilakukan dengan pembuatan peternakan sendiri.
Pembuatan peternakan ini selain untuk mendukung kelangsungan bahan baku bagi perusahaan, juga untuk memudahkan menjaga kualitas susu yang dihasilkan. Kualitas bahan baku harus terjaga untuk meningkatkan kualitas produk yang dihasilkan dan juga menjaga kepercayaan pelanggannya dengan bahan baku yang terlacak. Hal ini sesuai dengan penelitian Arjakusuma et al. (2013) yang menyatakan bahwa strategi yang seharusnya dilakukan untuk meningkatkan rantai nilainya adalah dengan meningkatkan kualitas bahan baku susu segar yang dipasok ke XYZ. Kualitas bahan baku juga harus dapat dilihat dari keterlacakan bahan baku. Isu ini menjadi isu penting bagi masyarakat yang mengonsumsi produk olahan. Penelitian Zhang et al. (2012) menyebutkan bahwa pelanggan lebih memilih untuk membeli produk yang terlacak sumber bahan bakunya karena memiliki sertifikat keamanan pangan yang lebih baik. Hal ini juga sejalan dengan penelitian Prastiwi dan Setiyawan (2016) yang mengatakan bahwa pengontrolan dan pengawasan kualitas susu cair perlu dilakukan di Indonesia. Oleh karena itu, adanya peternakan milik perusahaan akan membantu perusahaan dalam memastikan kualitas bahan baku susu segar dan menjaga kualitas produk olahan susu yang akan diproduksi. Selain untuk memastikan kualitas, adanya peternakan juga perlu dilakukan karena perusahaan berencana untuk melakukan ekspor produk olahan susu ke negara yang memberikan persyaratan keterlacakan bahan baku. Ayodele (2012) mengatakan bahwa arah pengembangan layaknya sebuah visi yang dimiliki perusahaan sehingga dapat menjadi kerangka kerja yang mengarahkan masa depan perusahaan secara nyata. Adapun strategi perbaikan bisnis XYZ dapat dilihat pada Gambar 3.

\begin{tabular}{|c|c|c|c|c|}
\hline Key Partner & Key Activities & Value Proposition & Customer Relationship & Customer Segment \\
\hline \multirow[t]{3}{*}{$\begin{array}{l}\text { 1. KUD Susu sekitar } \\
\text { 2. Perusahaan produksi } \\
\text { kemasan } \\
\text { 3. Perusahaan pakan** } \\
\text { 4. BPTU, UPTD** }\end{array}$} & $\begin{array}{l}\text { 1. Pemasaran } \\
\text { 2. Distribusi } \\
\text { 3. Produksi* } \\
\text { 4. Produksi bahan baku } \\
\text { susu** }\end{array}$ & \multirow{3}{*}{$\begin{array}{l}\text { 1. Sifat baru } \\
\text { 2. Kinerja } \\
\text { 3. Image } \\
\text { 4. Aksesibilitas } \\
\text { 5. kenyamanan } \\
\text { 6. Penambahan varian } \\
\text { rasa baru** }\end{array}$} & $\begin{array}{l}\text { 1. Saluran komplain } \\
\text { 2. Sales penjualan } \\
\text { langsung } \\
\text { 3. Saluran komunikasi } \\
\text { media sosial* }\end{array}$ & \multirow[t]{3}{*}{$\begin{array}{l}\text { 1. Keluarga dengan } \\
\text { ekonomi menengah ke } \\
\text { atas* } \\
\text { 2. Keluarga dengan } \\
\text { ekonomi menengah ke } \\
\text { bawah* }\end{array}$} \\
\hline & Key Resources & & Channel & \\
\hline & $\begin{array}{l}\text { 1. Intangible* } \\
\text { 2. Tangible- } \\
\text { peternakan** }\end{array}$ & & $\begin{array}{l}\text { 1. Saluran langsung* } \\
\text { 2. Saluran tidak langsung }\end{array}$ & \\
\hline \multicolumn{2}{|l|}{ Cost Structure } & & \multicolumn{2}{|c|}{ Revenue Streams } \\
\hline \multicolumn{2}{|c|}{$\begin{array}{l}\text { 1. Produksi } \\
\text { 2. Distribusi } \\
\text { 3. Biaya karyawan bagian peternakan** }\end{array}$} & & \multicolumn{2}{|c|}{ 1. Penjualan produk olahan susu dari produk terbaru* } \\
\hline
\end{tabular}

Gambar 3. Strategi perbaikan XYZ $\left({ }^{*}\right.$ meningkatkan; ${ }^{* *}$ menciptakan) 
Adanya peternakan sapi akan membuat elemen mitra kunci mengalami perubahan. Mandaka dan Hutagaol (2005) menyatakan bahwa permasalahan di bagian peternakan meliputi produktivitas yang masih rendah, kurangnya ketersediaan bibit sapi perah, biaya pakan yang tinggi, skala pemilikan kecil, dan mutu sumber daya manusia yang masih rendah. Namun, hal yang dianggap memberatkan adalah kurangnya ketersediaan bibit sapi perah dan biaya pakan yang tinggi. Permasalahan ketersediaan bibit sapi perah dapat diatasi dengan pemilihan bibit sapi perah yang berasal dari indukan yang telah terseleksi. Indukan ini dapat tersedia di dalam negeri maupun di luar negeri. Indukan yang berasal dari dalam negeri bisa didapatkan pada instansi pemerintah yang bertugas untuk menyediakan bibit unggul seperti BPTU dan UPTD yang berasal dari pemerintah. Sapi perah membutuhkan pakan ternak yang sesuai agar dapat memproduksi susu secara optimal. Agar sapi tersebut dapat berproduksi secara optimal maka XYZ dapat bekerja sama dengan perusahaan pakan untuk merumuskan pakan terbaik. Perumusan pakan ternak ini membutuhkan pengetahuan dan keterampulan peternak agar terwujudnya kesesuaian antara pakan dengan sapi. Asmara et al. (2016) menekankan bahwa peningkatan pengetahuan dan keterampilan peternak dalam menjalankan usaha ternak perlu terus dilakukan.

\section{Aktivitas Kunci}

Adanya peternakan sapi dapat mengubah model bisnis yang dilakukan saat ini. Produksi bahan baku susu segar yang dilakukan secara sendiri dapat meningkatkan pasokan bahan baku susu segar yang akan membantu dalam memenuhi kapasitas produksi yang belum maksimal. Santosa et al. (2013) menyatakan bahwa produktivitas yang rendah dapat ditingkatkan melalui perpaduan dari pengalaman beternak dengan perkembangan IPTEK yang ada. Aktivitas produksi bahan baku susu segar pada XYZ harus dilakukan dengan mempertimbangkan faktor teknologi dan pengetahuan peternakan dari peternak seperti penggunaan mesin perah otomatis yang mengakibatkan kondisi bahan baku lebih steril daripada pemerahan secara manual.

\section{Struktur Biaya}

Adanya peternakan akan mengubah aktivitas yang dilakukan. Aktivitas yang dilakukan akan semakin bertambah dan itu tentu akan menambah struktur biaya dengan adanya penambahan biaya yang meliputi biaya SDM, biaya pakan ternak.

\section{Dalil Nilai}

Permasalahan yang dialami oleh pelanggan dapat menjadi sebuah tantangan bagi XYZ untuk mengeluarkan produk yang sesuai dengan permasalahan yang dialami tersebut. Adanya peternakan membuat XYZ dapat mengembangkan produktivitas susu yang dihasilkan dan membuat produk baru yang diinginkan oleh pelanggan. Penambahan varian rasa baru yang sesuai dengan keinginan pelanggan dapat menarik pelanggan baru dan meningkatkan loyalitas pelanggan lama.

\section{Segmen Pelanggan}

Peluang dari segmen pelanggan adalah adanya segmen pelanggan yang belum terlayani. Salah satu segmen baru yang saat ini sedang berusahan dilayani oleh XYZ adalah segmen pelanggan keluarga menengah ke bawah. Segmen ini memerlukan produk khusus karena cukup sensitif terhadap harga. Oleh karena itu, penawaran produk yang sesuai akan menarik pelanggan baru dari segmen pelanggan yang ini, seperti produk susu UHT ukuran mini ataupun yogurt kecil ukuran $70 \mathrm{ml}$.

\section{Saluran}

Komunikasi langsung antara perusahaan dan pelanggan merupakan salah satu saluran yang paling efektif untuk menjangkau pelanggan, sementara itu internet merupakan cara yang paling murah untuk menjangkau pelanggan (Slavik dan Bednar, 2014). Kegiatan promosi produk baru XYZ melalui saluran tidak langsung dapat dilakukan melalui internet, dengan menggunakan berbagai situs media sosial yang dimiliki, seperti instagram, twitter, facebook, dll. Penggunaan media sosial Pengenalan produk baru melalui situs juga harus dilakukan pada website perusahaan.

\section{Hubungan Pelanggan}

Elemen hubungan pelanggan perlu ditingkatkan melalui layanan personal dengan memanfaatkan media sosial yang telah dimiliki oleh XYZ. Hal ini dilakukan untuk meningkatkan dan mempertahankan intensitas komunikasi antara pelanggan atau calon pelanggan dengan perusahaan seperti yang dilakukan oleh Boedianto dan Harjanti (2015) yang melakukan peningkatan intensitas hubungan dengan pelanggannya. 


\section{Aliran Pendapatan}

Aliran pendapatan yang diterima oleh XYZ lebih banyak berasal dari pelanggan secara langsung. Pelanggan membeli berbagai macam produk olahan susu secara langsung melalui toko yang milik perusahaan atau sales penjualan langsung, ataupun secara tidak langsung melalui pihak retail, dan toko kelontong. Peningkatan aliran pendapatan setelah mendapatperbaikan akan tetap berasal dari penjualan produk olahan susu, khususnya yogurt. Namun, peningkatan ini juga dimunculkan oleh adanya penjualan produk baru.

\section{Implikasi Manajerial}

Penelitian ini dilakukan untuk menyusun strategi perbaikan yang bisa berdasarkan hasil evaluasi BMC. Berdasarkan hasil penelitian, strategi yang dapat dilakukan adalah peningkatan pada elemen sumberdaya kunci, yaitu dengan membuat peternakan milik sendiri yang dapat digunakan untuk memenuhi kebutuhan bahan baku susu segar untuk kegiatan produksi. Implikasi manajerial yang bisa diberikan berdasarkan hasil tersebut adalah dengan membuat studi kelayakan peternakan. Pembuatan studi kelayakan ini mencakup skala usaha yang akan dibuat, kapasitas produksi yang diharapkan, dan manajemen usaha ternak Pembuatan studi kelayakan ini mencakup skala usaha yang akan dibuat, kapasitas produksi yang diharapkan, dan manajemen usaha ternak. Skala usaha yang untuk peternakan yang diharapkan adalah skala usaha peternakan untuk kapasitas produksi berkisar 40-50 ton per hari. Besaran kapasitas produksi susu segar ini didapatkan dari kapasitas produksi produk olahan susu yang masih bisa dimaksimalkan dengan tambahan 40-50 ton per harinya. Penggunaan teknologi juga diharapkan akan menambah produktivitas susu segar. Pemilihan sapi perah merupakan salah satu hal penting yang perlu dilakukan. Sapi yang memiliki produktivitas susu tertinggi adalah sapi Freisian Holstein. Pemilihan jenis ini akan sesuai dengan pemenuhan kebutuhan susu segar yang selama ini belum bisa terpenuhi dalam memenuhi kapasitas produksi, terutama dalam mencoba kemungkinan ekspor produk olahan susu ke luar negeri yang harus mempunya keterlacakan bahan baku asal. Namun, perlu perhitungan yang matang agar dapat disesuaikan dengan kondisi-kondisi yang dimiliki oleh perusahan.

\section{KESIMPULAN DAN SARAN}

\section{Kesimpulan}

Model bisnis Cimory memperlihatkan bahwa segmen pelanggan XYZ adalah keluarga dengan kemampuan ekonomi menengah atas dan bawah. Produk yang ditawarkan meliputi sifat baru, kinerja, image, aksesibilitas, dan kenyamanan. Saluran yang dijalankan adalah saluran langsung dan tidak langsung. Hubungan pelanggan dijaga dengan adanya saluran komplain, saluran komunikasi media massa, dan sales penjualan langsung. Aktivitas yang dilakukan meliputi produksi, pemasaran dan distribusi yang didukung sumber daya tangible dan intangible dan memiliki partner KUD susu, dan perusahaan produksi kemasan. Pendapatan didapatkan dari penjualan produk olahan susu dan pengeluaran biaya meliputi produksi, gaji karyawan, dan distribusi produk.

Hasil evaluasi dari hasil SWOT BMC memerlihatkan adanya kekuatan utama yang berasal dari elemen hubungan pelanggan. Sementara itu kelemahan utama terdapat pada struktur biaya karena kegiatan produksi yang belum berjalan secara efisien. Peluang terbesar berada pada elemen segmen pelanggan karena adanya segmentasi pasar baru yang belum terjangkau secara maksimal. Sementara itu, ancaman terbesar berada pada sumberdaya kunci karena adanya ancaman kelangkaan bahan baku susu segar.

Strategi yang dapat dilakukan adalah mengoptimalkan elemen sumberdaya kunci, yaitu dengan adanya pembuatan peternakan milik perusahaan yang bisa dilakukan oleh perusahaan untuk mengurangi ancaman kelangkaan bahan baku. Peternakan ini sendiri harus berada dekat dengan pabrik sehingga kuantitas, kualitas dan keberlanjutan bahan baku dapat terjamin.

\section{Saran}

Penelitian ini menekankan pada pengembangan strategi perusahaan berdasarkan perspektif BMC. Berdasarkan hasil analisis yang telah dilakukan, terdapat beberapa hal yang dapat dikaji secara lebih mendalam seperti penelitian tentang perencanaan strategik untuk mengetahui tahapan-tahapan pengembangan model bisnis yang lebih terukur yang menggunakan penilaian prioritas untuk pengembangan bisnis 


\section{DAFTAR PUSTAKA}

Al-Debei MM, Avison D. 2010. Developing a unified framework of the Business Model Concept. European Journal of Information Systems 19 (3): 359-376.https://doi.org/10.1057/ejis.2010.21.

Amanullah ANAA, Aziz NFA, Hadi FNHAH, Ibrahim J. 2015. Comparison of business model canvas (BMC) among the three consulting companies. International Journal of Computer Sciences and Information Technology Research 3(2): 462471.

Arjakusuma RS, Hartoyo S, Fahmi I. 2013. Rantai nilai pada industri susu studi kasus pt cisarua mountain dairy (cimory). Jurnal Manajemen dan Agribisnis 10(1): 22-31.

Asmara A, Purnamadewi YL, Lubis D. 2016. Keragaan produksi susu dan efisiensi usaha peternakan sapi perah rakyat di indonesia. Jurnal Manajemen \& Agribisnis 13(1):14-25.https://doi.org/10.17358/ JMA.13.1.14.

Ayodele IO. 2011. The role of strategic vision process in business development in nigeria. Global Journal of Management and Business Research 11(9): 16-21.

Boedianto, Harjanti D. 2015. Pengembangan bisnis pada depot selaris dengan pendekatan business model canvas (BMC). Agora 3(2): 292-301.

Bonazzi FLZ, Zilber MA. 2014. Innovation and Business Model: a case study about integration of innovation funnel and business model canvas. Review of Business Management 16(12): 616637.

Chesbrough H.2005. Open Innovation: A New Paradigm for Understanding Industrial Innovation Chapter 1. Oxford: Oxford University Press.

Dudin MN, Lyasnikov NV, Leont'eva LS, Reshetov KJ, Sidorenko VN. 2015. Business model canvas as a basis for the competitive advantage of enterprise structures in the industrial agriculture. Biosciences Biotechnology Research Asia 12(1): 887-894. https://doi.org/10.13005/bbra/1736.

Farid M, Sukesi H. 2011. Pengembangan susu segar dalam negeri untuk pemenuhan kebutuhan susu nasional. Buletin Ilmiah Litbang Perdagangan 5(2): 196-221.

Giesen E. Riddleberger E, Christer R, Bell R. 2010. When and how to innovate your business model. Journal of Strategy and Leadership 38 (4) : 17-26. https://doi.org/10.1108/10878571011059700.
Jackson A, Harjanti D. 2015. Evaluasi dan perancangan model bisnis pada kaisar organizer dengan business model canvas. Agora 3(2): 302-309

[Kemenperin] Kementrian Perindustrian. 2017. Indonesia mengimpor 3,65 juta ton susu setiap tahun. http://www. kemenperin.go.id/ artikel/18427/Indonesia-Mengimpor-3,65-JutaTon-Susu-Setiap-Tahun [2018 Oktober 05].

[Kementan] Kementerian Pertanian. 2016.Outlook Susu Komoditas Pertanian Subsektor Peternakan. Jakarta: Pusat Data dan Sistem Informasi Pertanian Sekretariat Jenderal Kementerian Pertanian.

Mandaka S, Hutagaol MP. 2005. Analisis fungsi keuntungan, efisiensi ekonomi dan kemungkinan skema kredit dengan pengembangan skala usaha peternakan sapi perah rakyat di kelurahan kebon pedes kota bogor. Jurnal Agro Ekonomi 23(2): 191-208. https://doi.org/10.21082/jae. v23n2.2005.191-208.

Oktariani A. 2014. Daya saing usaha ternak sapi perah dengan pemasaran susu segar berbasis agrowisata [thesis]. Bogor: Institut Pertanian Bogor.

Osterwalder A, Pigneur Y. 2010. Business Model Generation. New Jersey: John Wiley \& Sons, Inc.

Prastiwi WD, Setiyawan H. 2016. Perilaku konsumsi susu cair masyarakat di daerah perkotaan dan pedesaan. Agriekonomika 5(1): 41-53. https:// doi.org/10.21107/agriekonomika.v5i1.996.

Rangkuti F. 2005. Analisis SWOT Teknis Membedah Kasus Bisnis. Jakarta: Gramedia Pustaka Utama.

Santosa SI, Setiadi A, Wulandari R. 2013. Analisis potensi pengembangan usaha peternakan sapi perah dengan menggunakan paradigma agribisnis di kecamatan musuk kabupaten boyolali. Buletin Peternakan 37(2): 125-135.https://doi. org/10.21059/buletinpeternak.v37i2.2431.

Slavik S, Bednar R. 2014. Analysis of business models. Journal of Competitiveness 6(4): 19-40. https:// doi.org/10.7441/joc.2014.04.02.

Somantri GG, Satria A, Iskandar BH. 2017. Analisis model bisnis pt. Pahala bahari nusantara dengan menggunakan pendekatan model bisnis kanvas. Albacore 2(1): 1-12.https://doi.org/10.29244/ core.2.1.1-12.

SusantoH,DaryantoA, SetiawanI.2017.Pengembangan model bisnis daur ulang sampah plastik di CV majestic buana group. Jurnal Manajemen IKM 12(1): 46-62. https://doi.org/10.29244/ 
mikm.12.1.48-62.

Tsai HM, Lin YD, Su YH. 2011. A grounded theory on the business model structure of google. Journal Business Management 9(3): 231-242.
Zhang C, Bai J, Wahl TI. 2012. Consumers' willingness to pay for traceable pork, milk, and cooking oil in nanjing, china. Food Control 27(3): 21-28. https://doi.org/10.1016/j.foodcont.2012.03.001. 